\title{
Rapping in Catalan in Class and the Empowerment of the Learner
}

Despite the well-known educational possibilities afforded by Rhythm And Poetry (RAP) for the development of musical, lyrical and critical skills (Morrell \& Duncan-Andrade, 2002; Hill, 2009; Low, 2011), it remains a lyrical genre often excluded from Catalan secondary education. This paper focuses on a 4-day series of rap workshops given in 2012 by a famous local Catalan rap artist in a multicultural and multilingual state school in Catalonia. It analyses the impact that the workshops had, above all in terms of classroom engagement, linguistic empowerment and textual "agency" (Moje \& Lewis 2007), on a range of students with varying degrees of command of the Catalan language and with different degrees of experience with rap music. Through the classroom activity described herein, we show the pedagogical opportunities that rap music offers as a hybrid text in-between oral and written codes that makes it a powerful vehicle for selfexpression, whilst enabling the acknowledgement of real uses of languages and genres related to the cultural practices of urban students, in the classroom. In particular, we argue that bridging Catalan rap culture to the goals of the school curriculum, especially in highly multilingual and multicultural school contexts, helps to promote the socialisation of the Catalan language in and beyond the school.

Keywords: hip-hop pedagogy; linguistic empowerment; secondary education, third space theory; youth vernacular literacies.

\section{Introduction $^{1}$}

This paper focuses on a series of rhyme workshops given in a high school in Catalonia by Pau Llonch, lead vocalist of At versaris, one of the few current groups that rap in the Catalan language. In this study we depart from the observation that rap music is often

\footnotetext{
${ }^{1}$ This paper is co-authored by those who participated in the research, assuming different roles: Júlia-Alba Fernández is the teacher who organised the rhyme workshops by linking them to the school curriculum of some compulsory and optional modules on music, Pau Llonch gave the sessions and Cristina Aliagas observed this educational experience through the lens of educational research, without intervention
} 
misunderstood, marginalised and even, at times, disdained both in Catalan literacy research and in educational settings. Nevertheless, we believe that rap is a cultural practice that has value in Education as a space for challenge and change, as we will demonstrate through a qualitative analysis of how the series of workshops empowered the students. More specifically, we argue that using Catalan rap music in the classroom as a vehicle for the student's self-expression can help learners to challenge negative linguistic preconceptions and attitudes towards Catalan by revealing that they can express their ideas successfully in that language. This type of educational approach is particularly relevant in Catalonia, a bilingual area where newcomers are inclined to favour Spanish as the international language and see Catalan as the institutional language of the school. Feeling competent in the language, at least at a colloquial level, might also be beneficial for those students, either newcomers or native speakers, who struggle with the academic register in Catalan, since difficulty with the medium can have a negative impact on their academic achievements and motivations.

This paper draws on the body of research undertaken in the field of hip-hop studies, which comprises research on hip-hop literacies (Richardson, 2006) and hip-hop in education (Petchauer, 2009). Considering that many of these studies come from English speaking academic contexts, this paper seeks to show the pedagogical contribution that Catalan rap music can offer in the Catalan secondary school system, above all as a tool to engage students in using Catalan to express themselves. This paper also draws on the concepts of "a third space of learning" (Moje et al., 2004) and "funds of knowledge" (González, Moll, \& Amanti, 2005), which have been adopted by research in the Literacy Studies tradition that looks at the use of teenagers' everyday cultures and literacies in the classroom (e.g. Pahl \& Rowsell, 2005). As we will explain later on, we use those concepts as analytical lenses to explore how and to what extent 
the series of rhyme workshops had an impact on the students' perceptions of themselves as speakers of Catalan. Since Catalan is the vehicular language of the educational system in Catalonia, we see this impact as a form of academic empowerment for some students.

This paper is organised as follows. First, we situate our research within the field of hip-hop pedagogy and we present the theoretical apparatus that guided our analysis of this educational experience, taking a sociocultural approach to learning grounded in Third Space Theory and focusing on how the students were empowered. Second, we describe the methodological approach that informed our data collection and analysis during and beyond the workshops. Third, we describe the rhyme workshops, the curricular goals pursued, the participants and the target project, which was to perform a song in a rap-based Christmas concert. Fourth, we present our findings by focusing on the linguistic engagement with Catalan and the textual achievements of some students with differing academic trajectories, differing levels of command of the language and different degrees of experience with rap music. A final discussion about the pedagogical possibilities for the use of Catalan rap in secondary education concludes our article.

\section{The hip-hop pedagogy approach to learning}

Rhythm And Poetry (or rap) is a musical style based on rhymes that originated in the Bronx, New York, during the early 1970s. It emerged as a new site and medium for social protest. It evolved within hip-hop culture, a mass youth culture involving, as defining actors, disc jockeys (DJs/turntablists), emcees (MCs), breakdancers (b-boys and b-girls), and graffiti writers (aerosol artists). Rap music is an art which articulates three components: "content" (usually critical messages about social issues), "flow" (rhythm and rhyme) and "delivery" (the performance). The texts are delivered in time to a beat, a feature that distinguishes rapping from spoken poetry. Rap texts can be written 
to be recorded for a large audience or based on free styling improvisation (e.g. "battles", or "cyphers"). Rap music relies on mass media techniques and technologies (e.g. turntables, vinyl records, mixers), and much of its content comes from both mass and high culture; this polyphonic feature is the substance of its critical content.

Rap music has been regarded with contempt in research and education to an extraordinary extent, especially in Catalonia and Spain. The scant amount of research on rap culture undertaken in Spain is limited to sociological investigation (Reyes, 2007) or focused on a closed rhetoric-based analysis of the literary devices of lyrics (Pujante, 2009). This might be due to the widespread representation of rap music as a peripheral discourse in society - typically associated with gangs, street violence and misogyny something that makes, as Valenta (2013) found, educational actors believe that 'all' lyrics transmit messages unsuitable for children through inappropriate, explicit and vulgar language. However, hip-hop culture is far more socially and academically valued in other countries, such as the USA or Brazil, where there is a well-established body of research, known as hip-hop studies, which cover the subfields of hip-hop literacies and hip-hop pedagogy.

On the one hand, the field of hip-hop literacies (e.g. Newman, 2005; Alim, 2006; Richardson, 2006; Culter, 2014) includes sociolinguistic-based studies that look at the culture of Hip-hop, including issues of identity, ideology, language and the vernacularity of the text. On the other hand, hip-hop pedagogy (e.g. Morell \& DuncanAndrade, 2004; Petchauer, 2009; Kinney, 2012; Leigh, 2013) brings together reflections and classroom experiences pointing to the pedagogical uses of hip-hop and how it can be integrated into the classroom praxis. In general, the underlying assumption of these studies is that the culture of hip hop can be used as a 'bridge' to scaffold certain school curriculum goals, such as boosting critical reading (Hill, 2009), bringing poetry closer 
to the world of the students (Morell \& Duncan-Andrade, 2004; Leigh, 2013) or improving academic literacy (Sánchez, 2010; Christianikis, 2011).

Hip-hop pedagogy, which form the main frame for our research, connects with the powerful urge, felt over recent decades by researchers involved with home-school literacy (Pahl \& Rowsell, 2005), to connect home and school experiences in learning, above all in relation to language and popular culture. The underlying assumptions of home-school literacy research at the core of hip-hop pedagogy are that connecting students' vernacular literacies to formal learning encourages rich "third spaces of learning", which might empower the students by having a positive impact on their attitudes to language, literacy and schooling.

\section{Third space theory and the learner's funds of knowledge}

Within Sociocultural Pedagogy, and drawing on hybridity theory (Bhabha, 1994), third space theory (Moje et al., 2004) posits that young people learn by constantly crossing boundaries between practices, discourses and literacies. It looks at learning using the idea of "social spaces". These are conceptualised as spheres of practice that are coarticulated in people's everyday lives, and organised as a continuum. The "first space" is associated with the discourses of people's homes, community, and peer networks, and the "second space" embraces those other discourses associated with institutions, such as work or school. The "third space" emerges when the "first" and the "second" spaces coarticulate, engendering a "third" interstitial one where people's ways of knowing, thinking and doing, typically associated with different spheres of practices, learn to coexist. In the alternative "third space" the established cultural identifications of the "first space" and the "second space" are transgressed, subverted and transformed in new, creative ways. 
In pedagogical terms, third space theory favours a socially connected approach to learning aimed at overcoming the gap between the in-school and out-of-school spheres of practice, each one with its own values and literacies. In that regard, it acknowledges the student's "funds of knowledge" as key resources for learning in the classroom. Therefore, young people are seen as competent individuals that might enhance school by bringing to the classroom the cultural heritage, concepts and ways of knowing that they have developed within their families, communities and peernetworks. They also bring their "funds of identity" (Esteban-Guitart \& Moll, 2014), that is to say, their own discourses, meanings and artefacts by means of which they understand and produce themselves.

Moje et al. (2004) argue that in education there are three main views of the third space:

- as a 'bridge' that enables the connection between marginalised and conventional forms of knowledge and discourses,

- as a 'navigational space' where students draw from their own "funds of knowledge" to make sense of the specialised texts of the curricular content areas,

- as a 'space of change' wherein everyday and academic knowledge, cultures and literacies are challenged precisely as new knowledge is generated.

Regardless of the metaphor, third space theory challenges the idea of the student as a passive subject continuously shifting between different systems of knowing. On the contrary, the student is seen as the subject who actively articulates the different discourses, practices and knowledge she or he encounters in everyday life. In other 
words, according to third space theory students are seen as being "in-between" systems of knowledge but conceptualised as active "meaning-makers" (Wells, 1986).

\section{Rap as a hybrid text and the empowerment of the learner}

Written rap lyrics are "hybrid texts" (Christianakis, 2011) between a written and an oral text, in between poetry and music. A rap lyric is a text written to be shared orally and that is why the text itself is imbued with a "flow" (rhythm and rhyme) during its creation. The "delivery" or "performance" is one of the aspects that makes rap different from recited poetry despite the common features they share, such as rhyming, rhythm, verse stress construction, alliteration, assonance and consonance (Attridge, 2002).

Some researchers have demonstrated that what the hybrid nature of rap lyrics does as a vehicle of expression is valuable for the achievement of literacy goals, both as a frame for meaning-making and as textual material open to deep analysis and critical interpretation. Leigh (2013) views hip-hop lyrics as texts that offer many pathways to literacy content and skills in terms of literary devices, language, storytelling and social critique. Others (Labov, 1972; Alim, 2006; Kinney, 2012) have shown that AfricanAmerican students who struggled or resisted expressing themselves through the language of academic discourse could express themselves in moving ways through the complex discourse of rapping. Sánchez (2010), in a study including critical analysis of hip-hop texts, showed that the integration of vernacular and academic discourses encouraged students to speak of themselves and their personal interests, using their own language in an essay. These studies show young people empowered by the hip-hop medium, as it helped them to act as self-assured text producers and interpreters of hiphop texts in the classroom. In terms of pedagogy, they also show that the recognition of hip-hop culture in the classroom can create a fruitful "third space of learning" where the "funds of identity" (Esteban-Guitart \& Moll, 2014) and the personal histories of the 
learners can enhance formal learning by boosting their textual "agency" (Moje \& Lewis, 2007), that is to say, their ability to act through texts within particular sociocultural contexts structured by relations of power.

In that regard, our data show that using rap texts as resources for expression in the classroom can empower the learner textually, linguistically and culturally. The empowerment is a consequence of putting a vernacular text that is typically a "site of resilience" (Kinney, 2012) in the centre of the pedagogic arena, as this fact changes the values and rules of literacy expression in the classroom, in terms of content, form and language. One of these changes has to do with the typical first person voice of rap music, which encourages the emergence of "developmental narratives" (Travis, 2013), that is to say, narratives around stories or thoughts that reflect learning, growth, selfesteem and change. Another feature is that rap texts lie in between orality and writing, and in between formal and informal discourse, and it is precisely this hybridity that enables a more fluid self-expression. These hybridity features offer more opportunities for students to coordinate form, content and performance through their textual choices and, in short, they give more textual agency to the students.

\section{Goals and methodology}

This paper seeks to analyse a series of rhyme workshops given by a professional rap artist through the following research question: What were the ways in which the students were empowered in the course of the workshops and beyond? The analysis mainly focuses on the student's textual responses and linguistic attitudes to the target activity, which consisted of writing a rap lyric in Catalan. It articulates two focuses: in the class and beyond. On the one hand, we wanted to research the impact of the workshops on the students' attitudes towards the Catalan language by looking at their song writing and performances. On the other hand, we were also interested in 
researching the impact that the workshops had on those participating students who were involved in the local hip-hop scene, where Spanish is still the prestigious language for rapping (Palà, 2010). For this reason, we carried out two pieces of fieldwork: the first in-school, during the workshops, and the second outside of school, based on three casestudies.

Regarding the methodology of this study, we relied on qualitative case-study procedures (Yin, 1984). In order to devise our research approach to the rhyme workshops, we collected many and diverse qualitative data:

- 12 video-recorded sessions (4 lessons for each participating group).

- 12 audio recordings of the song writing period in each session, where the students were allotted time to write and rehearse their lyrics. The digital recorder was held by the singer or sometimes located on top of particular students' desks.

- Draft versions of the lyrics (up to 2 drafts and 1 final version from each student, 138 in total).

- Brief unstructured conversations with some students after the lessons.

- Informal meetings between the teacher, the singer and the researcher during break times and class displacements.

- Field notes of the researcher.

- A reflective diary written by the teacher.

The second fieldwork had an 'ethnographic quality' and focused on the casestudy of three students (one boy and two girls) involved in the local rap scene. For one year we documented their out-of-school hip-hop-based literacy practices, including their online and offline spheres of practice. The data included: 
- Access to their social networks (mainly Facebook, Twitter and SoundCloud),

- 4 interviews with them at different moments in time,

- 3 video recordings of their rap performances in different spaces of their lives (e.g. the park, the street).

In terms of the analysis, we combined two approaches to the interpretation of our data. On the one hand, we analysed the data qualitatively, focusing on particular issues, such as how the contents of the series of workshops were built up, the students' positioning in the activity and their written and oral achievements in the song writing and final performance. On the other hand, we also triangulated the data (e.g. videos, drafts, field notes, interviews) by focusing on particular students across the sessions. For each of them, we looked at their attitudes towards the Catalan language during the workshops, the thematic and linguistic changes in their drafts and their performances in the Christmas concert. For the three students who participated in the second fieldwork, the cross-case analysis included their own hip-hop texts.

\section{The rhyme workshops}

\section{Site and the socially-committed culture of the secondary school}

INS Lluís de Peguera, the high school where this research was conducted at the end of 2012, is a state institute of secondary education (IES) located in the heart of Manresa, a mid-size city, $65 \mathrm{~km}$ from Barcelona. During the second half of the $20^{\text {th }}$ century, work in the textile industry attracted new residents to the city, mainly from the south of Spain and more recently the city has been populated increasingly by international newcomers, chiefly with Latin-American and North African backgrounds. This social reality has had an impact on the school, which has become multilingual and multicultural. 
INS Lluís de Peguera is a "green and supportive school"2, respecting the natural environment and committed to the promotion of social equality. Since the nineties, both staff and students have organised activities for the city (eg. talks, workshops, cinema sessions, concerts) and have been involved in demonstrations of solidarity, events such as campaigns to collect food, solidarity gymkhanas ${ }^{3}$, selling postcards to raise money for specific causes (such as paying a study grant for a child in Rwanda) and painting a mural promoting world peace. Through this voluntary work the secondary school hopes to raise social awareness within the school and in the city.

The Music Department of the school participates actively in these sociallycommitted activities with concerts, musicals or one-off performances. Some of these contributions are organised in the classroom and assessed. The rhyme workshops being analysed in this paper were one of those activities designed to promote social awareness, since they culminated in a Christmas rap concert for the school. The teacher who organised them believes that the pressure to produce output with social impact is a powerful motivator for her students, and so her underlying teaching philosophy centres around a project-based learning approach where students design, plan and carry out an extended activity that culminates in a final exhibition of work for an audience.

\section{Participants}

${ }^{2}$ The Green School Programme (Programa Escoles Verdes) was launched by the Department of Environment and Sustainability of the Catalan Government in 1999. The schools involved integrate the goal of generating positive attitudes towards the environment in their strategic school plan. Lluís de Peguera secondary school has extended this goal to society as well.

${ }^{3}$ A "gymkhana" is a competition based on consecutive physical challenges. In a "solidarity gymkhana" the money collected is given to welfare with the goal of addressing social needs. 
The workshops were partially funded ${ }^{4}$ by Casa de la Música (The Music house) in Manresa (see Image 1), which is an institution leading a social project devoted to the creation, public performance, teaching and dissemination of modern music, local and international. With that particular activity, the choice to disseminate Catalan rap among teenagers implied a linguistic as well as musical dimension to the proposal. It was offered to several local schools but only a few teachers, like Júlia-Alba, decided to take it on.

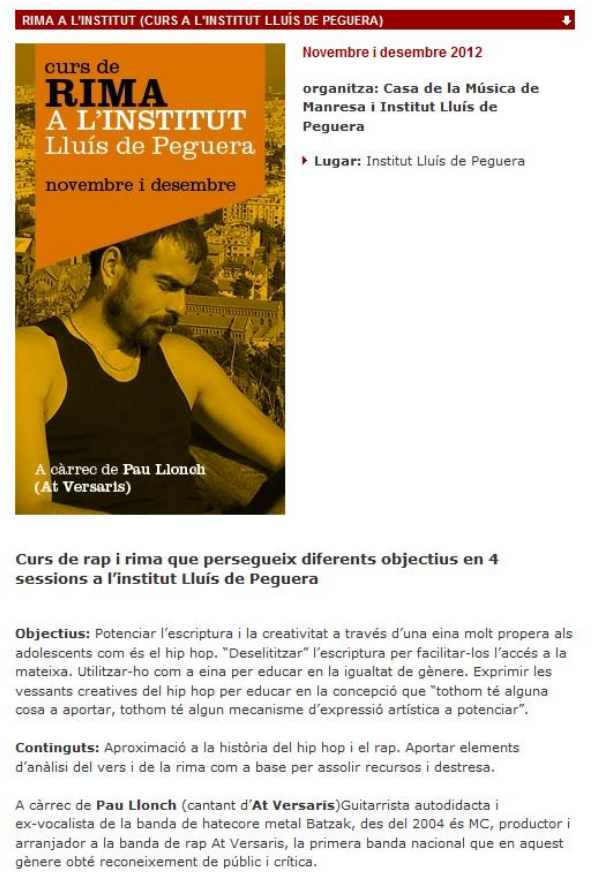

Image 1. Poster published in Catalan on the Casa de la Música website to promote the rhyme workshops.

The rhyme workshops were given to three groups, with a total of 75 students, as presented in Table1.

Table 1. The participants.

\footnotetext{
${ }^{4}$ Families paid 4 euros in total, which consisted of 1 euro per session.
} 


\begin{tabular}{|l|l|l|}
\hline Subject & Course & Participants (quantity) \\
\hline Music (compulsory) & $3^{\text {rd }}$ year of Secondary & Group A (27) \\
Education (15-16 year old) & Group B (22) \\
"Fem un musical" (Let's & $2^{\text {nd }}$ year of Bachillerato (last & 1 group (26) \\
(optional for the & year of secondary school, 17- & \\
dramatic arts branch) & 18 year old) & \\
\hline
\end{tabular}

In these groups, different languages and background cultures coexisted. Around $40-45 \%$ of the students in the $3^{\text {rd }}$ year of secondary education (15-16 year old) were Latin-American (e.g. from Peru, Ecuador, Bolivia) or from the Maghreb, a percentage that dropped to $5 \%$ in the last year of secondary school (17-18 year old). Based on the researcher's observations of student interactions during the class and during the transits between classrooms, the Castilian variant of Spanish was the language dominating peertalk between students. This was confirmed later by several teachers from the school in informal conversations. This observation was consistent with the findings of sociolinguistic-based fieldwork in similar multilingual schools in Catalonia (Woolard, 2009; Trenchs-Parera \& Patiño-Santos, 2013), where it was found that teenage students of immigrant backgrounds do not favour Catalan as a language for peer-group relationships, since they usually perceive it as a language to be reserved for school. This perception is socially and politically grounded in a bilingual area with a long history of uneasy coexistence between the two languages; typically, each is associated with

\footnotetext{
${ }^{5}$ Original title in Catalan: Fem un musical
} 
different social identities, ideologies and social spheres (e.g. Catalan is the vehicular language of education), but the associations are more complex when analysed in the light of diverse sociocultural contexts. Newcomers usually see Spanish as the international language, more useful as a lingua franca and significantly more embedded in popular music, whilst Catalan is seen as an institutional language with less presence in their social circles. In that regard, the workshops contributed to the socialisation of the Catalan language among the students, since in the course of the workshops they produced and shared their lyrics in Catalan.

\section{An idol in the class}

The rhyme workshops were given by Pau Llonch (blog: http://paullonch.cat/category/blog/), lead vocalist of At versaris, with the support of the teacher, who helped in particular activities. He brought into the classroom his own conceptions of language, writing and pedagogy. In terms of language, he brought the idea that rapping in Catalan is as legitimate as rapping in Spanish. At versaris represents an inflexion point in the history of rap, as it was the first group that demonstrated that rapping in Catalan was possible (Palà, 2010). Within the world of rap music, At versaris have challenged the dominant ideology according to which Catalan is not a suitablesounding language for "doing" rap, as it is socially constructed as a highly normalised, prescriptive language in comparison with Spanish, which is seen as less rigid (Enderrock, 2009) and possessing more 'street cred'. From the outset, the group's linguistic philosophy was to rap using the language that young people speak in the streets, that is to say, with colloquialisms and Castilian linguistic forms, and it was this philosophy that the rap singer tried to transmit to the students in the workshops. As the 
students were also writing down their raps, they felt able to bring writing closer to speaking.

In terms of pedagogy, Pau brought his own ways of understanding teaching and learning as a process centred on practice, the expression of self and connected to everyday experiences. He tried to frame the classroom as a social place by valuing participation, exchange, rap-related sorts of 'play' (e.g. nonsense rhymes) and incidental learning. He extended the possibilities of learning to body movement and slang. Moreover, he based his relationship with the students on a sort of confidence (e.g. "I know you can do it"), encouragement and constructive feedback. All these elements constituted ways in which the students were empowered during the rhyme workshops.

\section{Goals and structure of the rhyme workshops}

The educational aims that shape the music curriculum are formulated as three main areas: meaningful listening, vocal and instrumental performance, and composition. They seek to improve the student's ability to understand, reflect and (re)create current local and historical music in personal, critical and imaginative ways. In Júlia-Alba's class the students learned about several musical genres, such as traditional music (e.g. Christmas songs, sardanes), popular music (e.g. jazz, rock, rhythm and blues) and classical music (e.g. opera, choral music). That year, she decided to enhance the students' training by adding the genre of written rap music. Obviously, this content implied a connection with those students in the classroom who listened to rap music or were involved in the local hip-hop scene; a comparable connection to the sessions on rock or choral music generate with other students. The teacher integrated the rhyme workshops within the school curriculum with the following goals: 
- To learn more about the history of rap music worldwide and locally, its style and expressive capabilities.

- To help the students express their own ideas through music, trying to find their own balance between the rhythm, the verse and their critical viewpoints on the world.

- To contribute to other basic cross-curricular communicative competencies, such as instrumental competences (oral and written expression in Catalan), interpersonal (critical thinking, ethics and commitment, self-motivation) and systemic (creativity, personal initiative, management by goals, concern for quality).

Beyond the musical content of the workshops, the teacher sought to empower the students in the classroom by giving them the chance to express their own ideas in everyday Catalan. She believed that formal written Catalan was a barrier for many students who did not manage to express the complexity of their thinking through that medium. Therefore, bringing rap texts into the classroom was a way to create a different site of expression that emphasised informal uses of Catalan and allowed the students to express themselves through a "hybrid discourse" (Christianakis, 2011) between literacy and orality. Thus, both empowerment and promoting Catalan were part of the teacher's agenda.

Below, Table 2 summarises the general contents of the workshops, which took place once a week over the period of a month (November/December 2012). Over the four sessions, the students produced a draft, wrote and then performed their own freelythemed one-minute rap lyrics in Catalan. In those moments dedicated to individual song writing, an instrumental backing track was played in the classroom. 


\begin{tabular}{|c|c|c|}
\hline Sessions & Contents and Activities & $\begin{array}{l}\text { Student's output: a } \\
\text { rap lyric to be } \\
\text { performed in the } \\
\text { Christmas concert }\end{array}$ \\
\hline $\begin{array}{l}\text { Session } 1 \\
\text { The history of rap, and its } \\
\text { poetical and rhythmical } \\
\text { basis }\end{array}$ & $\begin{array}{l}\text { History of hip-hop } \\
\text { Rap lyrics within hip-hop } \\
\text { culture } \\
\text { Musical features: flow, beat, } \\
\text { loops } \\
\text { Lyrical resources: alliteration, } \\
\text { metaphor, repetitions... }\end{array}$ & Draft 1 \\
\hline $\begin{array}{l}\text { Session } 2 \\
\text { Interpretative analysis and } \\
\text { improvisation exercises }\end{array}$ & $\begin{array}{l}\text { Analysis of lyrics in English, } \\
\text { Spanish and Catalan } \\
\text { Short rhyme exercises }\end{array}$ & Draft 2 \\
\hline $\begin{array}{l}\text { Session } 3 \\
\text { Live writing and the } \\
\text { rehearsal }\end{array}$ & $\begin{array}{l}\text { Time to convert Draft } 2 \text { into the } \\
\text { final version } \\
\text { Time to do an individual } \\
\text { rehearsal }\end{array}$ & $\begin{array}{l}\text { Final version of the } \\
\text { draft }\end{array}$ \\
\hline $\begin{array}{l}\text { Session } 4 \\
\text { Rapping the verses }\end{array}$ & Rehearsal with the class & $\begin{array}{l}\text { Performance of the } \\
\text { lyric in front of } \\
\text { classmates }\end{array}$ \\
\hline \multicolumn{3}{|c|}{ CHRISTMAS CONCERT } \\
\hline
\end{tabular}

Table 2. The workshops, session by session 


\section{Findings: focusing on the mobilisation of languages, texts and ideas}

In the following section, we give a global analytical account of the workshops in the light of third space theory to show the ways in which the workshops empowered the students and contributed to the mobilisation of their agency linguistically, textually and socially. In the course of the analysis we will also explore the students' attitudes towards Catalan as a language for rapping.

\section{Playing with the resonant aesthetics of the Catalan and Spanish languages}

Catalan was the vehicular language of the rhyme workshops, since it is the official language of instruction in the Catalan education system. This was a ground rule that several students brought to the fore at the end of the first workshop, when they had some free time to begin to think about their own lyrics. The question "Can we write the song in Spanish?" arose repeatedly. Certainly, this question was legitimate socially speaking, since rap in Catalan is barely visible in the music industry in Catalonia (Palà, 2010). At that point, the students were drawing on their "funds of knowledge" as music consumers and trying to challenge the curriculum. Faced with that question, Pau responded by encouraging them to "play" with the sounds of both languages.

Byron, the only non-local student in the Bachillerato optative class Let's make a musical was one of the students who preferred to do his rap in Spanish. He was Peruvian and was 17 at that time. At the end of the first session, Byron presented a 
blank page as his draft (Image 2). He was worried about the activity and said, in Spanish, to the teacher "the problem is I don't know how to do this"

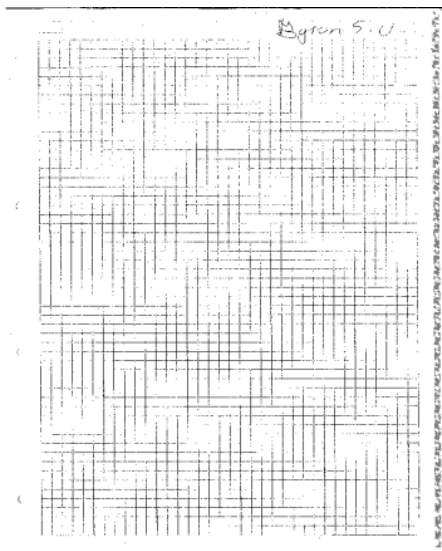

Image 2. Byron's draft in Image 3. Byron's draft in

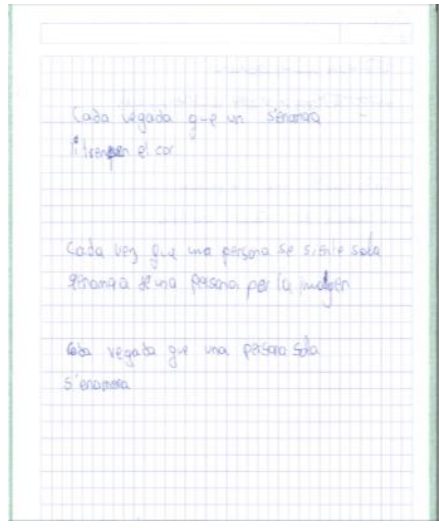

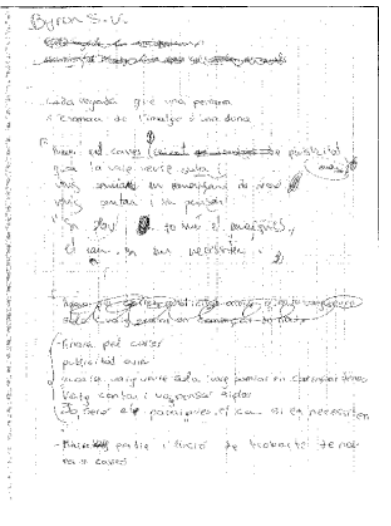

Image 4. Byron's draft in session 1. session 2. session 3.

In session 2, Byron asked for Pau's assistance and they collaboratively explored the resonant aesthetics of the languages through an invented example. This conversation seemed to make Byron more relaxed about the language barrier and he then focused on the phonetic effects of one verse of his song (Image 3) that he had written first in Catalan, then in Spanish, and then in Catalan again. In the course of the translations, the content of the verse was modified and the final version, in Catalan, ended up being the title of his lyrics: "Each time that someone falls in love with the image of a woman". By the third session (Image 4), Byron had managed to write a brief rap lyric about unconditional love for a girl and his desire to protect her like an umbrella on a rainy day. Gaining autonomy in writing shows a process of taking control over learning and

${ }^{6}$ Original in Spanish: es que yo no sé hacer esto. Note that, except in data involving multilingual interaction, quotations of oral and written texts have been translated from Catalan/Spanish into English in the main text with the original provided as a footnote. When possible, the translation seeks to represent the style of spelling, grammar, punctuation and register of the original text.

${ }^{7}$ Original in Catalan: cada vegada que una persona s'enamora de la imatge d'una dona. 
thus is evidence of textual "agency" (Moje \& Lewis, 2007). Byron had moved from a situation where he felt overwhelming linguistic and discursive constraints (session 1) to one in which he experimented with the language (session 2) until finally feeling free enough to express his story (session 3), which emerged as follows:

Walking down the street

adverts all around

When I saw her alone,

I dreamt of starting again

I sang and I thought please

I will be your umbrella,

your shelter if you need $\mathrm{me}^{8}$.

\section{The intersection between the word and the world}

Rap artists usually draw inspiration from their local contexts in order to question hegemonic representations (Richardson, 2006). The students quickly picked up this principle and consistently enhanced their song writing with the 'hot' political and social topics of the moment, such as the debate on the independence of Catalonia and the corruption of politicians. Expressing unique thoughts in a knowledge-driven context, such as the school, is a form of empowerment and agency. A range of topics were chosen by the students, which included recounting relationships (e.g. love, friendship, bulling, chauvinism) and deep critiques of economic and social inequalities, politics or the pantomime of Christmas festivities. A comparison of the students' first and last

\footnotetext{
${ }^{8}$ Original in Catalan: Tirava pel carrer / publicitat arreu / Quan la vaig veure sola, / vaig somiar en començar de nou / vaig cantar i vaig pensar sisplau / jo seré el paraigües, / el cau si em necessites.
} 
drafts shows how quickly they shifted from creating lyrics with naïve content that rhymed, to creating lyrics containing strong social critiques and explicit language. The thematic evolution that took place evidences how the rap genre encouraged the students to act through their lyrics, as they made important thematic, textual and linguistic choices in order to recount their thoughts, beliefs and feelings.

When Hasan and Zakariah (both 14 years old), two other newcomers in the school, came from Morocco, they spent two years in a reception class in order to learn Catalan. This was their first year in the mainstream class (in the $3^{\text {rd }}$ year of secondary education) and, although they were able to express themselves orally in Catalan, they were still struggling with academic Catalan. Over the course of the workshops, they both achieved the writing and performance of a short but linguistically appropriate rap where they developed, often in co-ordinated segues, their critical insights into racism and poverty.

The day of the performance, Hasan began by rapping:

If I'm of one colour or another one

it don't mean that I'm different.

I'm here all day,

fighting for my rights.

If you're black or white,

we're no different ${ }^{9}$.

And then Zakariah took his turn to explain his theory linking poverty and smoking:

\footnotetext{
${ }^{9}$ Original in Catalan: Si sóc d'un color o d'un altre / no vol dir que sigui diferent. / Tot el dia estic aquí, / lluitant pels meus drets. / Si ets negre o blanc,/ no som diferents.
} 
People spend all day

smoking cigarettes and joints.

Life goes on and on

and people smoke too much.

When people have problems

they pass the time smoking

because food is so expensive ${ }^{10}$.

In common with others in the class, Hasan and Zakariah acted as text producers in Catalan. Certainly, their written text had some orthographic mistakes but this was secondary to an activity that was focused on self-expression in Catalan through music. Their successful oral performance in the concert, which was resoundingly applauded, left a positive linguistic experience in their trajectory as learners and speakers. Moreover, they also acted as interpreters of their worlds. They took advantage of the activity to express their own social views and share them in front of the school community. The rap texts became a "third space" in itself where the language of the school (Catalan) and the students' concerns, values and ideas intersected and transformed self-perceptions and social identities by challenging expectations about language, self-expression and values.

Connecting cultures and languages through rap music

${ }^{10}$ Original in Catalan: La gent passa el temps / amb cigarros, fumant porros. / La vida passa i passa / i la gent fuma massa./ La gent quan té problemas / passa el temps fumant / perquè el menjar li costa tant. 
Otmane (14 years old, Morocco) joined the school on the third workshop, which was only his second class in this school. He sat down in the first row and quietly observed his new classmates writing and rehearsing their lyrics over a rhythmic backing track. He seemed somewhat bemused. Helped by Mehdi, a classmate from Morocco, the teacher spent some time with him and encouraged him to write a rap lyric in Arabic. As we will show, when Otmane entered the classroom this put the students from Morocco in a "third space of learning", as they drew on their own linguistic "funds of knowledge" in assuming the challenging role of mediating conversations and translating texts. At the same time, through that mediation Otmane was being socialised into the Catalan language.

By the end of the class, the teacher had a conversation with Otmane about his song, with the linguistic mediation of three Arab students: Hasan, Mehdi and Zakariah (Image 5). Otmane had written his song using the Arabic chat alphabet - a phonetic transcription of Arabic that uses Roman script and Arabic numerals, typically found on the Internet - and Hasan promptly complained, in Spanish: "It's very difficult to translate ${ }^{11}$, . However, the three students summoned all their patience and tried to translate Otmane's lyrics (Image 6), which were about the Palestinian war, word by word:

that's it

the war has started

Waiting

With

they're cocky

${ }^{11}$ Original in Spanish: Es muy difícil traducirlo. 
they don't listen

they're carrying (something) $)^{12}$
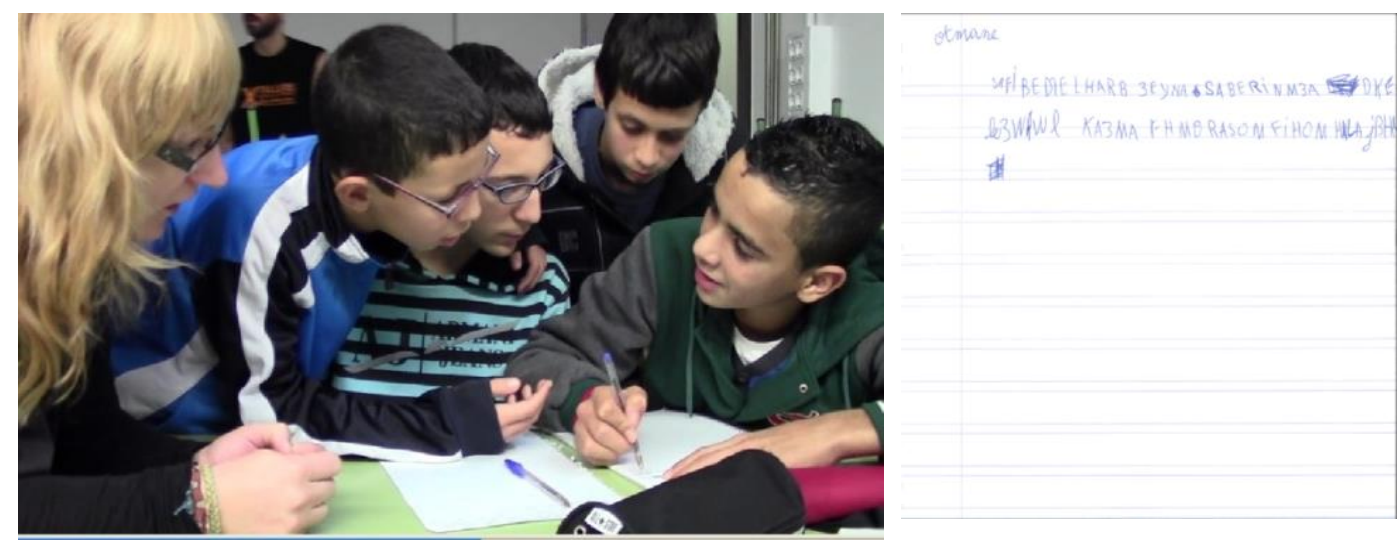

Image 5. Hassan, Mehdi and Zakariah (from left to Image 6. Otmane's lyrics.

right) helping Otmane to translate his rap lyrics for

the teacher (left) to understand.

Later on, we sought a more thorough professional translation of Otmane's text ${ }^{13}$ and were able to confirm that they had quite successfully translated some of the key words, although they had not been able to give an overall translation. In any case, since the translation was too fragmentary, the teacher formulated some questions for Otmane in order to understand his lyrics better. Mehdi facilitated that conversation in real time, assuming the role of "language broker" (Tse, 1995). He performed his role

${ }^{12}$ Original in Catalan: ja està / ha començat la guerra / amb / són xulos / ells no escolten / porten (alguna cosa).

${ }^{13}$ Translation into Spanish by Adil Moustaoui and Laura Mijares (Universidad Complutense de Madrid): "The war has already begun, we are tired withstanding the blows. The guys still don't understand, they are completely exhausted but even so, they are still bold" ( $\mathrm{Ha}$ empezado ya la guerra, estamos cansados aguantando los golpes. Los chicos aún no entienden, están hechos un desastre y aun así, atrevidos son). 
'professionally' and managed to coordinate the speakers and languages with astonishing dexterity.

\begin{tabular}{|c|c|c|c|}
\hline & Speaker & Talk Catalan/Arabic $^{14}$ & Translation into English \\
\hline 1 & Teacher & $\begin{array}{l}\text { a veure, el que jo no entenc } \\
\text { és... qui està escrivint això?? }\end{array}$ & $\begin{array}{l}\text { well, what I don't } \\
\text { understand is... who's } \\
\text { writing this? }\end{array}$ \\
\hline 2 & $\begin{array}{l}\text { Mehdi ((looking at } \\
\text { Otmane })\end{array}$ & $\begin{array}{l}\text { شكون اللي كا يكتب هاد الشي؟ } \\
\text { Ashkun eli ka-ykteb had } \\
\text { ashi? }\end{array}$ & Who's writing this? \\
\hline 3 & $\begin{array}{l}\text { Otmane }((\text { looking at } \\
\text { Mehdi }))\end{array}$ & و واحد خانا؟ & a tough guy \\
\hline 4 & $\begin{array}{l}\text { Mehdi ((looking at the } \\
\text { teacher }))\end{array}$ & un noi dur & a tough guy \\
\hline 5 & Teacher & $\begin{array}{l}\text { un noi, però parla de la } \\
\text { guerra? }\end{array}$ & $\begin{array}{l}\text { a boy, but is he talking about } \\
\text { the war? }\end{array}$ \\
\hline 6 & $\begin{array}{l}\text { Mehdi }((\text { looking at } \\
\text { Otmane }))\end{array}$ & على من كايهضر هاد الثي؟ & is he talking about the war? \\
\hline 7 & $\begin{array}{l}\text { Otmane }((\text { looking at } \\
\text { Mehdi }))\end{array}$ & على الحرب & yes, about the war \\
\hline 8 & $\begin{array}{l}\text { Mehdi ((looking at the } \\
\text { teacher }) \text { ) }\end{array}$ & de la Guerra ((capcinejant)) & about the war ((nodding)) \\
\hline 9 & Teacher & de quina Guerra? & about which war? \\
\hline
\end{tabular}

${ }^{14}$ Translation of the Arabic parts by Adil Moustaoui (Universidad Complutense de Madrid) and Maryam S. Alghafri (The University of Sheffield). 


\begin{tabular}{|c|c|c|c|}
\hline 10 & $\begin{array}{l}\text { Mehdi (looking at } \\
\text { Otmane }))\end{array}$ & quina Guerra? & what war? \\
\hline 11 & $\begin{array}{l}\text { Otmane ((looking at } \\
\text { Mehdi }))\end{array}$ & $\begin{array}{l}\text { فين هي هاد الحرب؟ } \\
\text { Fin hiya had al harb? }\end{array}$ & the Palestinian war \\
\hline 12 & $\begin{array}{l}\text { Mehdi ((looking at the } \\
\text { teacher }))\end{array}$ & الحرب في فلسطين & in Palestine \\
\hline 13 & $\begin{array}{l}\text { Teacher ((directly } \\
\text { looking at Otmane }))\end{array}$ & $\begin{array}{l}\text { de la guerra de Palestina? } \\
\text { del vídeo que hem vist abans? } \\
\text { ((assenyalant a la pantalla }))\end{array}$ & $\begin{array}{l}\text { about the Palestinian war? } \\
\text { Of the video that we } \\
\text { watched earlier? ((pointing } \\
\text { to the screen)) }\end{array}$ \\
\hline 14 & $\begin{array}{l}\text { Otmane ((directly } \\
\text { looking at the teacher }))\end{array}$ & $\begin{array}{l}\text { ((Afirma amb el cap, però } \\
\text { amb certa inseguretat })) \text {. }\end{array}$ & $\begin{array}{l}\left(\text { nods }_{2} \text { though somewhat }\right. \\
\text { uncertainly }))\end{array}$ \\
\hline
\end{tabular}

This exchange developed in a complex, shifting linguistic context that Mehdi successfully controlled by looking from one side to the other in order to converse either with the teacher or with Otmane in the appropriate language. However, in the final part of this naturally occurring interaction, Mehdi mixed up the languages and instead of translating the teacher's question into Arabic for Otmane to understand, he repeated it in Catalan, looking Otmane directly in the eye ("What war?", line 10). What is interesting is that, although Otmane felt a bit confused, he successfully answered the question (line 11) by stating that his song was about the Palestinian war. Just afterwards, the teacher, on impulse, asked Otmane directly (line 13), in Catalan and without looking at Mehdi, if his lyrics were about the video clip that was shown at the beginning of the class. Otmane seemed to deduce the meaning by context, since he answered by nodding (line 14). 
Otmane had been inspired by the images from a video clip of a rap song that was projected by Pau at the beginning of the class in order to frame a short warm-up activity. The images in the video clip were clearly associated with war. Later on, we realised that Otmane had written down the verses of an Arabic rap song that he knew, and that he had chosen a section that talked about a war. Be this as it may, for us this is an instance showing the extent to which music can facilitate understanding, since the video clip helped Otmane to pursue the goals of the activity, even though he failed to grasp the context. Furthermore, we see in this exchange an example of the way in which the workshop generated "third spaces of learning" between the student's "funds of [musical] knowledge" and the writing-based task.

The workshop was indeed an encounter between the different cultures, languages and 'musics' of the classroom, and this led to a range of "third spaces of learning" involving ideas, literacies and social attitudes that we do not typically find in a classroom. As the teacher stated in her final entry in the diary: "I must highlight the value that this workshop has had as a source of social cohesion and integration among the students, besides being a powerful motivator to write and talk in Catalan ${ }^{15}$,

\section{KlaRa and Yousra's language discoveries}

KlaRa (an 18 year old Catalan studying in her last year of secondary school) and Yousra (14, from Morocco in the $3^{\text {rd }}$ year of secondary education) discovered something inwardly important during the rhyme workshop. KlaRa had been a rapper since she was 15 years old and already had her Hip-hop name, "Kla-Ra", in which "Ra" is a reference to the Egyptian sun god. Over the course of the workshops, her rapping skills left

\footnotetext{
${ }^{15}$ Original in Catalan: Cal resaltar el valor que el taller ha tingut com a forma de cohesió social $i$ d'integració dels alumnes, a més d'un gran motivador per escriure i parlar en català.
} 
everybody astonished and her various displays of prowess during the sessions did trigger some jealousy amongst certain of her classmates. We came across evidence of this in the first draft of her song, where someone, jokingly and adopting the voice of a teacher, had written "Clearly not your own work. Mark: 4.5/10"16. Although she came from a Catalan-speaking family, she had always rapped in Spanish, following the tendency in the local music industry (Palà, 2010). In these workshops, she wrote and performed her first ever rap in Catalan, and later on she improved on it and uploaded it to SoundCloud". As she stated in a later interview with the researcher, "What the

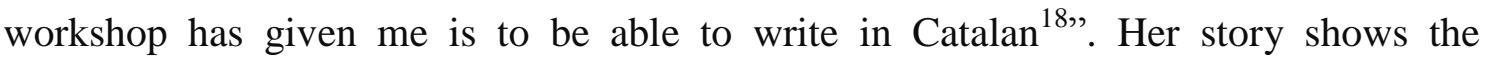
linguistic impact that the school-based workshop had in her trajectory as an emergent rapper.

Yousra, by contrast, had never written any lyrics of any kind, but her older brother was a break-dancer, so she had been exposed to rap music since a young age and developed her own latent "funds of knowledge" on rap literacies. In the Christmas concert, she performed her lyric with an extraordinary naturalness and left everybody amazed, including herself. The audience reacted with loud screams, showing that they had enjoyed her performance, and shouted in unison, in Spanish, "Yes, you're good! Yes, you're good! ${ }^{19}$, , a phrase coined as the title of a well-known talent show, aired on a national Spanish TV network. The students' reaction reveals to what extent a schoolbased activity can be reevaluated collectively within a new frame that connects school with students' out-of-school practices and literacies.

\footnotetext{
${ }^{16}$ Original in Catalan: Es nota que no es teu. Nota: 4.5/10.

${ }^{17}$ Soundcloud is an online site for sharing originally-created songs. It is particularly popular among aspiring rappers.

${ }^{18}$ Original in Catalan: A mi, el que m'ha aportat el taller, és escriure en català.

${ }^{19}$ Original in Spanish: Tú si que vales! Tú si que vales!
} 
Although KlaRa and Yousra were not classmates, their successes caused them to meet outside the workshop. KlaRa assumed the role of mentor, helping the novice Yousra to create her profile on SoundCloud and to socialise in the city's rap community. KlaRa gave her access to her own home-studio and helped her to record her new lyrics. Less than two months after the workshop, they had already done a rap together, in Spanish, and uploaded it to their SoundCloud profiles, where, for a year, the only rap in Catalan were those they did for the workshops. Their story, that began at school, shows to what extent a school-based activity can mobilise the student's learning out of school.

During our second period of fieldwork, out of school, we followed KlaRa and Yousra's rap-based literary activity in their social networks (Facebook, Twitter and SoundCloud) and interviewed them regarding the meanings that rap culture had in their lives. We also enjoyed their own Spanish raps, performed in the streets of Manresa. One of the goals of that fieldwork was to explore language ideologies in emergent rappers. The transcription below reproduces a short extract from a conversation between the teacher and KlaRa that happened in an alleyway where she used to meet up with other rappers. KlaRa reflects on her preference for rapping in Spanish, a choice influenced by the linguistic status quo in the rap culture and the desire to attract a wider public.

\begin{tabular}{|l|l|l|}
\hline & Speaker & Translation into English $^{\text {20 }}$ \\
\hline 1 & Júlia-Alba & what influence does the \\
language have? \\
\hline 2 & KlaRa & there aren't many singers in \\
\hline
\end{tabular}

\footnotetext{
${ }^{20}$ Júlia-Alba: quina influència té, la llengua? (2) KlaRA: no hi tants cantants en català (3) Júlia-Alba: hi ha At versaris (4) KlaRA: Ja ... però costa. A mi no em surt. No em surt. Ho estic intentant $i$ ara que ja he fet un tema, algo més caurà (...) però el castellà també arriba a més gent (...) amb això de la llengua no sé com posicionar-me.
} 


\begin{tabular}{|l|l|l|}
\hline 3 & Júlia-Alba & Catalan \\
\hline 4 & KlaRa & $\begin{array}{l}\text { there's At versaris } \\
\text { doesn't come easily. It } \\
\text { doesn't come out. I'm trying } \\
\text { and now I've done one song, } \\
\text { something more will come } \\
\text { (...) but also Spanish gets } \\
\text { through to more people (...) } \\
\text { with the language thing I } \\
\text { don't know how to position } \\
\text { myself }\end{array}$ \\
\hline
\end{tabular}

Certainly, KlaRa continued to rap in Spanish, since it remains the dominant language in the rap arena in Catalonia, but the workshop at least generated a Catalan rap song in Klara's career path, and raised a doubt within her, as she reveals that she does not know how to position herself regarding the language issue. One year after the workshop, she uploaded her first demo, entitled "Introspection" ${ }^{21}$ ", which included 6 songs, the second of which was in Catalan. This is evidence of how a school activity that sought to promote Catalan among teenagers through rap music had a small impact beyond school.

\section{Concluding comments}

\footnotetext{
${ }^{21}$ Original in Spanish: Introspección.
} 
In this paper, we have analysed a four-day rap-focused educational experience through the lens of third space theory, and we have looked particularly at how the use of song writing in the rap genre, in the context of classroom music, was able to challenge their attitudes to writing and Catalan language use.

Rap-based classroom activities reconfigure traditional educational hierarchies and boundaries by opening up a "third space of learning" between the school and the student's social life that might boost the learner's textual "agency" (Moje \& Lewis, 2007) and self-expression, and which has a positive impact on his/her perceptions as a speaker. We have shown that the rhyme workshops had just such a positive impact on the students' attitudes to writing and singing in Catalan, since they could call upon a wider range of linguistic and discursive repertoires to express their own creative ideas. Through the specific aesthetics of rap language, the students developed and conveyed attitudes towards life, using a stylised language, richly metaphorical and symbolic, to express the meanings they created. Moreover, they picked up the idea that the essence of rap music lies in its critical insights and challenging of establishment discourse, thus many engaged in the questioning of hegemonic representations related to power, politics, education, violence, classism, sexism or economic segregation. Others navigated a range of emotions and lived experiences, framing their lyrics as a space for self-expression.

Furthermore, the rhyme workshop had a positive impact on the students' attitudes towards the Catalan language because:

- it empowered the students linguistically, culturally and academically,

- it helped the students to construct positive identities in relation to the Catalan language and to allay personal linguistic apprehension, 
- it contributed to the students' evaluation of rap music as a complex, poetically-based literary practice and seeing Catalan as a relevant language for rapping.

The rhyme workshop validated the creative language of hip-hop within the culture of the school. Furthermore, because Pau, as a professional rapper, was sharing At versaris' philosophy of using Catalan as it is used in the streets, the workshop was also acknowledging real uses of the Catalan language in relation to the musical practices of urban students, within and beyond the classroom.

\section{Acknowledgement}

With the support of the Secretary for Universities and Research of the Ministry of Economy and Knowledge of the Government of Catalonia and the Co-funding programme of the Marie Curie Actions of the 7th R\&D Framework Programme of the European Union (Beatriu de Pinós 2011-A, 2013-2016). Moreover, Cristina Aliagas is part of a R\&D project financed by the Ministry of Science and Innovation in Spain for the period 1-1-2012 to 31-12-2014: "School 2.0: Digital literacy practices. Materials, classroom activity and online linguistic resources" (EDU2011-28381; directed by Dr. Cassany at Pompeu Fabra University. Site: https://sites.google.com/site/ies201x1/home ). We are grateful to Casa de la Música (The Music house) in Manresa for partially funding the workshop, to the families who also paid a part of it, and to the participating students of INS Lluís de Peguera for their wonderful rap lyrics. We are also grateful to Peter Skuce, who has contributed helpful and challenging linguistic revisions of this paper. 


\section{References}

Alim, H. S. (2006). Roc the Mic Right: The Language of Hip Hop Culture. New York: Routledge.

Attridge, D. (1995). Poetic Rhythm. An introduction. Cambridge University Press.

Bhahba, H. J. (1994). The location of culture. Oxon: Routledge.

Cutler, C. (2014). White Hip-Hoppers, Language and Identity in Post-Modern America. New York, NY: Routledge.

Christianakis, M. (2011). Hybrid texts: fifth graders, rap music and writing. Urban Education, 46(5), 1131-1168. doi: 10.1177/0042085911400326

Esteban-Guitart, M. \& Moll, L. (2014). Funds of identity. A new concept based on funds of knowledge approach. Culture \& Psychology, 20(1), 31-48. doi: $10.1177 / 1354067 X 13515934$

Enderrock (2009). At Versaris. Explosió de rap català [At versaris. Explosion of Catalan rap]. $\quad$ Enderrock, $\quad 168, \quad 7-13$. http://gb.zinio.com/www/browse/issue.jsp?skuId=416100857

González, N., Moll, L.; Amanti, C. (2005). Funds of knowledge: Theorizing practices in households, communities and classrooms. Mahwah, NJ: Erlbaum.

Hill, M. L. (2009). Beats, Rhymes, and Classroom Life: Hip Hop Pedagogy and the Politics of Identity. New York, NY: Teachers College Press.

Kinney, A. (2012). Loops, Lyrics, and Literacy: Songwriting as a Site of Resilience for an Urban Adolescent. Journal of Adolescent \& Adult Literacy, 55(5), 395-404. doi: 10.1002/JAAL.00048

Labov, W. (1972). Language in the Inner City. Studies in the Black English Vernacular. Philadelphia, PA: University of Pennsylvania Press. 
Leigh, L. (2013). Hip-Hop Literature: The Politics, Poetics, and Power of Hip-Hop in the English Classroom. English Journal 102, (5), 51-56. http://www.ncte.org/journals/ej/issues/v102-5

Low, B. E. (2011). Slam School: Learning Through Conflict in the Hip-Hop and Spoken Word Classroom. Chicago, IL: Stanford University Press.

Moje, E. B., Ciechanowksi, K. M., Kramer, K., Ellis, L., Carrillo, R., \& Collazo, T. (2004). Working toward third space in content area literacy. An examination of everyday funds of knowledge and discourse. Reading Research Quarterly, 39(1), 38-70. doi: 10.1598/RRQ.39.1.4

Moje, E. B. \& Lewis, C. (2007). Examining Opportunities to Learn Literacy: The role of critical sociocultural literacy research. In E. B. Moje, C. Lewis \& P. Enciso (Eds.), Reframing sociocultural research on literacy: identity, agency and power (pp. 15-48). Mahwah, N. J.; Lawrence Erlbaum.

Morrell, E. \& Duncan-Andrade, J. M. R. (2002). Promoting Academic Literacy with Urban Youth through Engaging Hip-hop Culture. The English Journal, 91(6), 8892. http://www.jstor.org/stable/821822

Newman, M. (2005). Rap as literacy: A genre analysis of Hip-Hop ciphers. Text \& Talk, 25(3), 399-436. doi: $\underline{10.1515 / \text { text.2005.25.3.399 }}$

Palà, R. (2010). El concurs Hip-hop.cat i la dinamizació del rap en català [The competition Hiphop.cat and the invigorating of Catalan rap]. Revista Tècnica de Política Lingüística, 49(1), 39-45. http://www.raco.cat/index.php/LlenguaUs/article/view/234300

Pahl, K., \& Rowsell, J. (2005). Literacy and Education. Understanding the New Literacy Studies in the Classroom. London: Sage.

Petchauer, E. (2009). Framing and Reviewing Hip-Hop Educational Research. Review of Educational Research, 79(1), 946-978. doi: 10.3102/0034654308330967 
Pujante, B. (2009). La retórica del rap. Análisis de las figuras retóricas en las letras de Violadores del verso [The rhetoric of rap. Analysis of the rhetorical figures in the lyrics of Violadores del verso]. Revista Electrónica de Estudios Filológicos, 17(1), w/p. http://www.um.es/tonosdigital/znum17/secciones/estudios-15.htm

Reyes, F. (2007). Hip hop, graffiti, break, rap, jóvenes y cultura urbana [Hip hop, graffiti, break, rap, youth and urban culture]. Revista de estudios de juventud, $78(1)$

125-139.

http://www.injuve.es/sites/default/files/2012/44/publicaciones/revista-78-capitulo$\underline{\text { 8.pdf }}$

Richardson, E. (2006). Hiphop Literacies. Oxon: Routledge.

Sánchez, D. M. (2010). Hip-Hop and a Hybrid Text in a Postsecondary English Class. Journal of Adolescent \& Adult Literacy, 53(6), 478-487. doi:10.1598/JAAL.53.6.4

Tse, L. (1995). Language brokering among Latino adolescents: Prevalence, attitudes, and school performance. Hispanic Journal of Behavioral Sciences, 17, 180-193. doi: $10.1177 / 07399863950172003$

Travis, Raphael (2013). Rap music and the Empowerment of Today's Youth: Evidence in Everyday Music Listening, Music Therapy, and Commercial Rap Music. Child \& Adolescent Social Work Journal, 30, 139-167. doi: 10.1007/s10560-012-0285-x

Trenchs-Parera, M. \& Patiño-Santos, A. (2013). Language attitudes of Latin-American newcomers in three secondary school reception classes in Catalonia. In J. Arnau (Ed.), Receiving Catalan at School: Challenges and Instructional Approaches (pp.49-71). Bristol: Multilingual Matters.

Valenta, S. (2013). Hip-Hop in Elementary Schools: Are We Really Listening Teachers? (Unpublished master's thesis). Buffalo State College, Buffalo, NY. 
Wells, G. (1986). The meaning makers: Children learning language and using language to learn. Portsmouth, NH: Heinemann.

Woolard, K. A. (2009). Linguistic Consciousness among Adolescents in Catalonia: A Case Study from the Barcelona Urban Area in Longitudinal Perspective. Zeitschrift fur Katalanistik, 22(1), 125-149. http://www.romanistik.unifreiburg.de/pusch/zfk/22/09_Woolard.pdf

Yin, R. K. (1984). Case study research (3th edition, 2003). Newbury Park, CA: Sage. 